\title{
Pengujian Sludge Battery Dengan Teknologi Microbial Fuel Cell Sebagai Sumber Energi Listrik Terbarukan
}

\author{
Ika Novia Anggraini, Afriyastuti Herawati, Ferdy Fajrian \\ Program Studi Teknik Elektro Universitas Bengkulu \\ Email : ikanoviaanggraini@gmail.com
}

\begin{abstract}
Microbial Fuel Cells are devices which convert chemical energy into electrical energy through catalytic reactions by microorganisms. In this study, the potential of electricity in MFC will be analyzed by using samples of sea mud, lake mud, land mud, and river mud. While the method used in this study is one series connected vessel, two vessels connected series with mud-water, two mud-mud series vessels, and the stack series method. The highest electrical conductivity produced by river mud reaches $3.63 \mathrm{mS} / \mathrm{cm}$, while the lowest is lake mud with a conductivity value of $0.35 \mathrm{mS} / \mathrm{cm}$. The highest electric power density produced by river mud by the two mud-mud vessel method is 46.766 $\mathrm{mW} / \mathrm{m} 2$, while the lowest electrical power density in lake mud is $18.040 \mathrm{~mW} / \mathrm{m} 2$. The highest electrical power is produced by river mud through a single vessel series system with a maximum power of 7.26 $\mathrm{mW}$, while the lowest power is found in marine mud with a system of two mud-water vessels which is equal to $0.30 \mathrm{~mW}$. The pattern of increase in voltage or current produced by the battery sludge is on average until the 7 th day, then a decrease occurs until the last day of testing. The greatest potential for electrical energy is obtained by river mud using a single vessel series system with a maximum voltage of $5.38 \mathrm{~V}$ and lasting up to 14 days.
\end{abstract}

Keyword : electric power density, microbial fuel cells, sludge battery

\section{PENDAHULUAN}

Laju pertumbuhan penduduk dan kemajuan teknologi berakibat pada peningkatan kebutuhan akan energy listrik. Hal ini berdampak pada berkurangnya cadangan energy fosil yang merupakan sumber energy utama dunia.

Hal ini memicu perkembangan penelitianpenelitian mencari alternatif energy baru yang dapat menghasilkan listrik. Di antaranya adalah baterai dari air laut (sea water battery) [1] dan baterai dari sampah kulit pisang dan kulit durian [2]. Akan tetapi kedua alternatif energi tersebut masih memiliki beberapa kekurangan, misalnya sea water battery tidak bisa diterapkan pada daerah pegunungan yang jauh dari laut serta mudahnya terjadi korosi pada batang anoda dan katoda sebagai media penghasil listriknya, sedangkan baterai dari sampah kulit pisang dan kulit durian masih memiliki masalah pada kondisi kelembaban yang tidak dapat berlebih sehingga listrik yang dihasilkan belum terlalu optimal. Oleh sebab itu, harus dicari alternatif energi yang dapat menghasilkan listrik secara efektif, efisien dan dapat digunakan secara luas dalam masyarakat.

Penelitian mengenai sumber energi terbarukan salah satunya adalah pemanfaatan energi dari teknologi Microbial Fuel Cell (MFC). MFC memanfaatkan materi organik yang digunakan oleh mikroba sebagai sumber energi dalam melakukan aktivitas metabolisme. Sel bahan bakar mikroba bekerja melalui aksi bakteri yang dapat mengantarkan elektron-elektron ke anoda. Elektron mengalir dari anoda melalui sebuah kawat ke katoda yang menghasilkan arus listrik [3].

Pada penelitian ini akan dirancang baterai dari lumpur (sludge battery) sebagai sumber energi baru terbarukan dengan memanfaatkan teknologi MFC dalam prosesnya menghasilkan listrik. Input keluaran dapat digunakan untuk sumber penerangan/lampu atau yang lainnya. Setelah itu akan dianalisa keluaran listrik yang dihasilkan dengan beberapa variasi lumpur endapan untuk memperoleh hasil yang paling efektif dan optimal.

\section{KERANGKA TEORITIS DAN PENGEMBANGAN HIPOTESIS}

\section{Microbial Fuel Cell (MFC)}

Microbial Fuel Cells adalah alat yang dapat mengubah energi kimia menjadi energi listrik melalui reaksi katalitik oleh mikroorganisme [4].

Prinsip kerja sistem MFC adalah bakteri pada bejana anoda mentransfer elektron dari donor elektron ke elektroda katoda. Bakteri yang hidup pada bejana anoda mengkonversi substrat seperti glukosa, asetat dan juga limbah cair menjadi $\mathrm{CO} 2$, proton dan elektron. Bejana anoda berada dalam kondisi anaerobik dan bakteri harus 


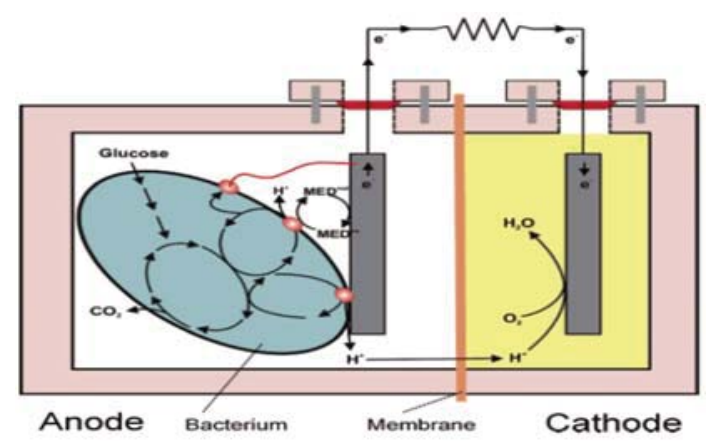

Gambar 1. Prinsip Kerja MFC [5]

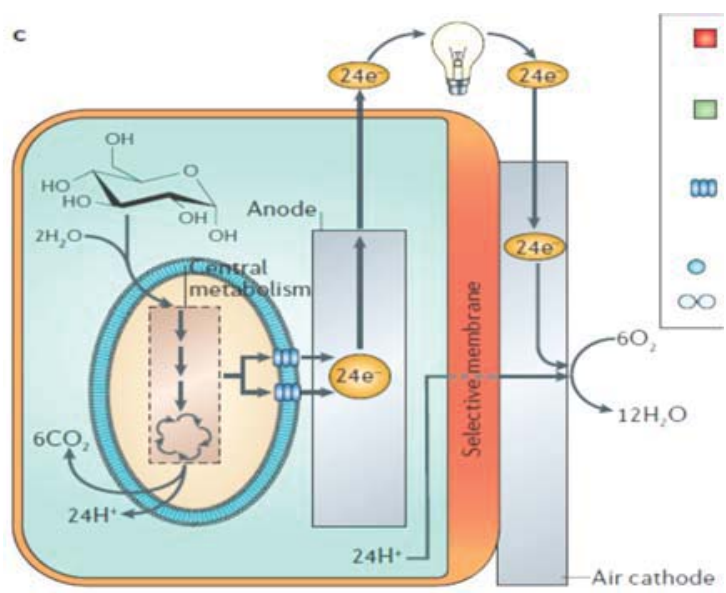

Gambar 2. Sistem Kerja MFC Satu Bejana [5]

mengubah penerima elektron alaminya menjadi penerima elektron insoluble seperti anoda. Penerimaan elektron ke anoda berlangsung melalui kontak langsung melalui kabel-kabel nano (nanowires) atau pengangkut elektron yang dapat larut. Selama produksi elektron, proton juga diproduksi dalam jumlah banyak. Proton ini bermigrasi melalui Proton Exchange Membrane (PEM) ke bejana katoda. Elektron mengalir dari anoda melalui hambatan luar ke katoda tempat bereaksinya penerima elektron (oksigen) dengan proton [5]. Berdasarkan reaksi pada elektroda, bioreaktor MFC dapat menghasilkan listrik dari aliran elektron di anoda ke katoda melalui rangkaian eksternal [6]. Gambar 1 menunjukkan prinsip kerja dari sistem MFC.

\section{Microbial Fuel Cell Satu Bejana}

Desain MFC yang sederhana dan efisien adalah MFC tanpa bejana katoda dan menempatkan katoda langsung dengan permukaan Proton Exchange Membrane (PEM).

Sistem MFC satu bejana, sistem dengan aliran yang berkelanjutan, dan tanpa membran merupakan sistem yang baik untuk pengolahan limbah cair karena dapat dikembangkan untuk skala besar.

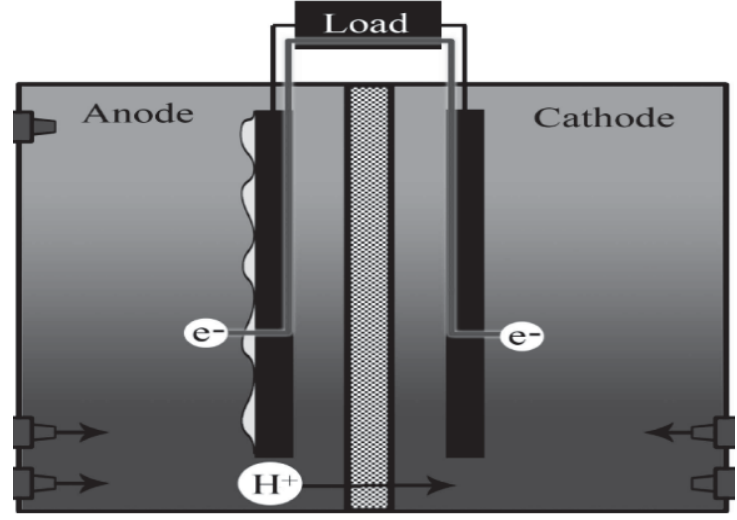

Gambar 3. MFC Dua Bejana [5]

\section{Microbial Fuel Cell Dua Bejana}

MFC dua bejana harus menggunakan Proton Exchange Membran (PEM) sebagai media transfer proton dalam sistem kerjanya, berbeda dengan sistem satu bejana yang memungkinkan PEM bisa tidak digunakan [5]. Gambar 3 menunjukkan MFC dengan sistem dua bejana menggunakan lumpur pada sisi anoda dan air pada sisi katoda.

Elektroda yang berfungsi sebagai anoda untuk kutub positif dan katoda untuk kutub negatif pada sistem MFC terdiri dari beberapa jenis, yaitu bisa menggunakan grafit karbon, seng, tembaga, atau karbon bambu. Pasangan dari elektroda MFC juga bisa divariasikan seperti : grafit-seng, tembaga-seng, grafit-grafit, atau karbon bambu-seng.

\section{Konduktivitas Listrik}

Konduktivitas berpengaruh dengan ionic strength atau kekuatan ionik pada MFC. Kekuatan ionik adalah kemampuan transfer proton dari sisi anoda ke sisi katoda berdasarkan nilai resistansi internal MFC tersebut [7].

Pada Persamaan 2, $\mathrm{R}$ adalah resistansi dalam substrat atau logam, dikarenakan resistansi bergantung pada bentuk konduktor, maka terdapat besaran yang disebut resistansi spesifik $\rho$, yang didefinisikan sebagai Persamaan 2.

$$
\rho=A R / b
$$

Keterangan :

$$
\begin{array}{ll}
\rho & : \text { Resistansi spesifik }(\Omega / \mathrm{m}) \\
\mathrm{R} & : \text { Resistansi }(\Omega) \\
\mathrm{A} & : \text { Luas penampang }\left(\mathrm{m}^{2}\right) \\
\mathrm{b} & : \text { Panjang elektroda }(\mathrm{m})
\end{array}
$$

Kebalikan dari resistansi spesifik tersebut dinyatakan sebagai konduktivitas listrik atau $k$ seperti yang ditunjukkan oleh Persamaan 3. Satuan konduktivitas listrik atau $k$ adalah $\mathrm{S} / \mathrm{m}$.

$$
k=1 / \rho
$$

Keterangan : 


\section{$k:$ Konduktivitas Listrik $(\mathrm{S} / \mathrm{m})$}

$\rho$ : Resistansi Spesifik $(\Omega / \mathrm{m})$

Pada MFC, besarnya konduktivitas listrik dipengaruhi oleh konsentrasi ion dan tahanan internal. Konduktivitas listrik akan semakin besar seiring dengan rendahnya tahanan internal MFC yang mengakibatkan kekuatan ionik MFC tersebut lebih besar sehingga jumlah zat yang mengion juga bertambah [7].

\section{Mekanisme Potensial Dalam MFC}

Pada internal MFC terdapat reaksi ion yang disebabkan oleh aktivitas bakteri atau mikroba dalam mengkonversi substrat organik. Dalam proses reaksi tersebut dihasilkan potensial reduksi dan potensial oksidasi. Pada MFC juga terdapat drop potential dari proses reaksi ion. Drop potential yang terjadi pada sistem MFC tersebut juga dikenal dengan istilah efficiency potential. Potensial reduksi dan potensial oksidasi dipengaruhi oleh jumlah elektron yang berhasil ditransfer dari elektroda anoda dan elektroda katoda pada sistem MFC. Proses inilah yang juga mempengaruhi besar tegangan keluaran yang dihasilkan oleh MFC, yang didefinisikan dalam Persamaan 4.

$$
\mathrm{V}_{\text {out }} \text { atau } \mathrm{E}_{\mathrm{MFC}}=\text { PE. }\left(\mathrm{E}_{\mathrm{Red}}-\mathrm{E}_{\mathrm{Ox}}\right)
$$

Keterangan :

$\mathrm{V}_{\text {out }}$ atau $\mathrm{E}_{\mathrm{MFC}}$ : Tegangan MFC (V)

PE : Potential Efficiency (V)

$\mathrm{E}_{\text {red }}$ : Potensial Reduksi (V)

$\mathrm{E}_{\mathrm{ox}}$ : Potensial Oksidasi (V)

Dari segi konstruksi MFC, tegangan keluaran dipengaruhi oleh ukuran permukaan elektroda.

\section{Densitas Daya listrik [8]}

Power Density atau densitas daya listrik adalah voltase $\left(\mathrm{E}_{\mathrm{MFC}}\right)$ yang dihasilkan oleh pasangan elektroda. Pada rangkaian MFC dipasang resistor sebagai tahanan eksternal $\left(\mathrm{R}_{\mathrm{ext}}\right)$. Daya listrik yang dihasilkan, dihitung dengan Persamaan 5.

$$
P=I x E_{M F C}
$$

Keterangan:

P : Daya Listrik (Watt)

I : Arus Listrik (Ampere)

$\mathrm{E}_{\mathrm{MFC}}$ atau V : Voltase (Volt)

Sesuai dengan hukum Ohm $\left(\mathrm{E}_{\mathrm{MFC}}=\mathrm{IR}_{\mathrm{ext}}\right)$ maka,

$$
P=E_{M F C^{2}} / R_{\text {ext }}
$$

Keterangan:

$\mathrm{R}_{\text {ext }}$ : Tahanan Eksternal (Ohm)

Densitas daya menyatakan besar daya listrik yang dihasilkan persatuan luas permukaan elektroda.

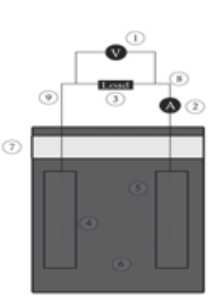

(a)

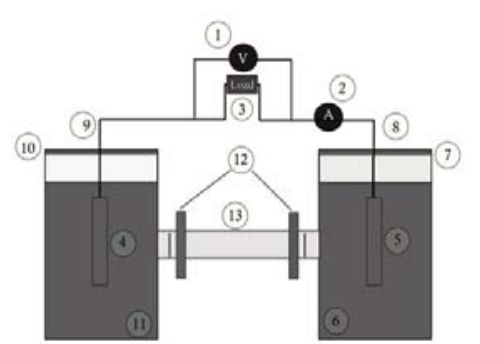

(b)
Gambar 4. Rangkaian MFC (a) Satu Bejana, (b) Dua Bejana

Keterangan Gambar 4 :

1. Voltmeter

2. Amperemeter

3. Beban (LED atau Resistor)

4. Elektroda Anoda

5. Elektroda Katoda

6. Substrat atau Lumpur

7. Wadah atau Bejana Plastik

8. Kabel Penghubung

9. Kabel Penghubung

10. Wadah atau Bejana Plastik

11. Substrat atau Lumpur

12. Penghubung Pipa

13. PEM (Proton Exchange Membran)

Densitas daya yang dinyatakan terhadap luas permukaan katoda dihitung dengan Persamaan 7 dan 8 .

$$
\begin{aligned}
P_{k a t} & =E_{M F C}{ }^{2} / A_{k a t} . R_{e x t} \\
P_{k a t} & =V x I / A_{k a t}
\end{aligned}
$$

Keterangan:

$\mathrm{P}_{\text {kat }}$ : Densitas Daya Listrik $\left(\right.$ Watt $\left./ \mathrm{m}^{2}\right)$

$\mathrm{E}_{\mathrm{MFC}} \quad$ : Voltase (Volt)

$\mathrm{A}_{\text {kat }}$ : Luas Katoda $\left(m^{2}\right)[2]$

\section{Pengujian Sludge Battery}

\section{METODE RISET}

Pada penelitian ini menggunakan sampel lumpur laut, lumpur danau, lumpur sawah, dan lumpur sungai yang didapat di area Provinsi Bengkulu dengan metode seri dan stack series. Sludge battery menggunakan elektroda tembaga dan seng sebagai anoda dan katodanya. Beban yang digunakan adalah resistor 1000 Ohm dan Light Emitting Diode (LED). Volume untuk tiap satu bejana dari sludge battery ialah $900 \mathrm{ml}$.

\section{Rancangan Penelitian}

Pada Gambar 4 merupakan rangkaian dari sistem MFC yang akan diterapkan pada penelitian ini.

\section{Tahap Perancangan Alat}

Perancangan alat sludge battery akan dibuat dengan sistem satu bejana dan dua bejana yang ditunjukkan oleh Gambar 5. Perancangan sludge battery secara keseluruhan dapat dilihat pada Gambar 6 . 


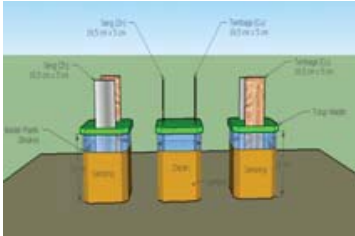

(a)

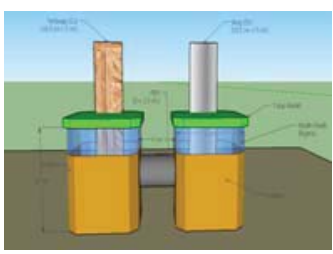

(b)
Gambar 5. Desain Sludge Battery (a) Satu Bejana, (b) Dua Bejana

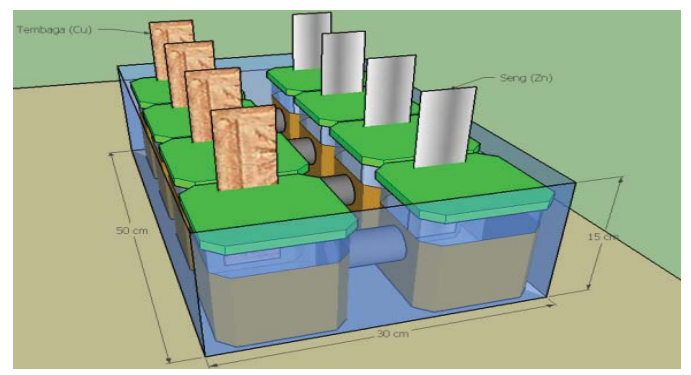

Gambar 6. Desain Sludge Battery keseluruhan

Berikut ini adalah gambar rangkaian pengujian sludge battery.

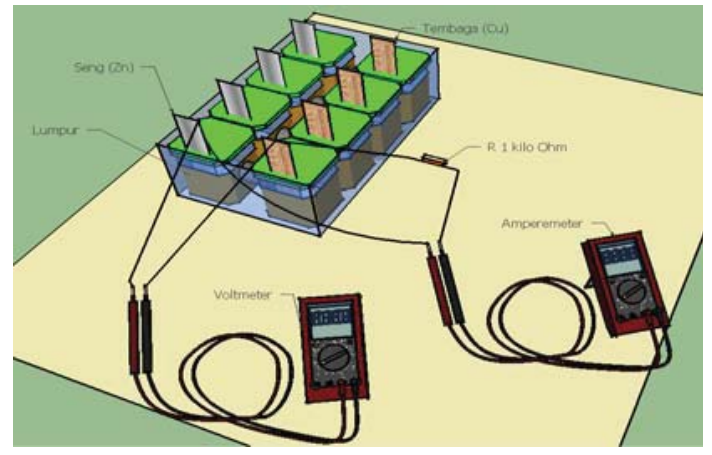

Gambar 7. Rangkaian Pengujian Sludge Battery

Pada Gambar 5 ditunjukkan desain sludge dengan sistem satu bejana ini akan menggunakan wadah/bejana dengan ukuran panjang $11 \mathrm{~cm}$, lebar $11 \mathrm{~cm}$ dan tinggi $12 \mathrm{~cm}$. Sepasang elektroda yang terdiri dari plat tembaga dan plat seng memiliki ukuran dengan panjang $19,5 \mathrm{~cm}$, lebar $5 \mathrm{~cm}$ dengan ketebalan masing-masing plat yang disesuaikan. Sludge battery dua bejana menggunakan PEM yang terbuat dari campuran agar dan $\mathrm{NaCl}$. Wadah PEM terbuat dari pipa dengan panjang $6 \mathrm{~cm}$ yang berdiameter $2,5 \mathrm{~cm}$.

Setelah itu dilakukan perancangan sludge battery secara keseluruhan. Sludge battery 8 bejana yang sudah disusun kemudian diletakkan di dalam wadah akrilik dengan ukuran panjang $50 \mathrm{~cm}$, lebar $30 \mathrm{~cm}$ dan tinggi $15 \mathrm{~cm}$.

\subsection{Diagram Alir Penelitian}

Proses penelitian sludge battery dapat dilihat pada Gambar 8 .

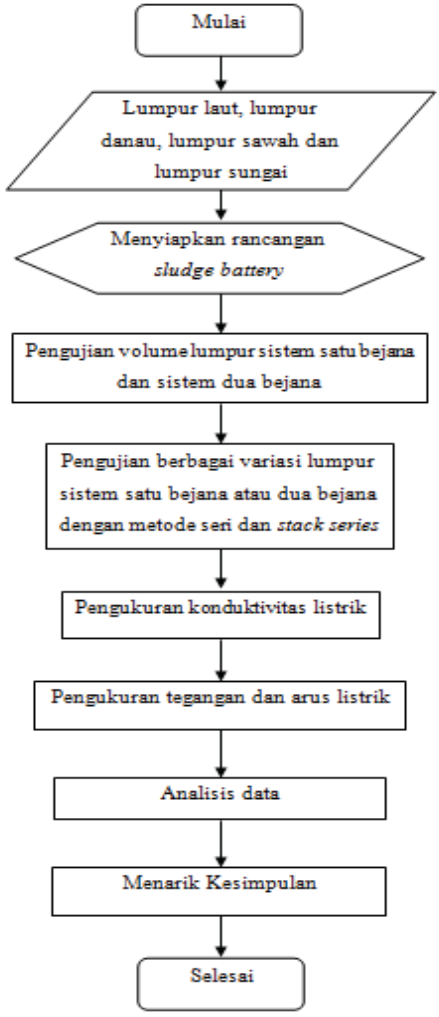

Gambar 8. Diagram Alir Tahapan Penelitian

4. HASIL DAN PEMBAHASAN

Hasil Pengujian Konduktivitas Listrik pada Sampel Lumpur dan Membran PEM

Tabel 1. Hasil Pengukuran Konduktivitas Listrik Jenis Sampel Konduktivitas Listrik $(\mathrm{mS} / \mathrm{cm})$

\begin{tabular}{cc} 
Lumpur Laut & 1,41 \\
Lumpur Danau & 0,35 \\
Lumpur Sawah & 2,58 \\
Lumpur Sungai & 3,63 \\
Membran PEM & 19,88 \\
\hline
\end{tabular}

Pada Tabel 4.1 didapat nilai konduktivitas listrik terbesar dari membran PEM yaitu 19,88 mS/cm. Hal ini disebabkan karena konsentrasi ion dari larutan membran PEM berasal dari $\mathrm{NaCl}$ yang memang memiliki jumlah zat mengion cukup besar. Nilai konduktivitas listrik suatu substrat atau larutan berpengaruh dengan kekuatan ionik pada MFC, yang berdampak pada proses transfer elektron dari elektroda anoda ke elektroda katoda dalam menghasilkan tegangan keluaran MFC.

\section{Hasil Pengujian Kelistrikan Sludge Battery}

Hasil pengukuran parameter listrik sludge battery dengan sistem satu bejana dan sistem dua bejana secara keseluruhan dapat dilihat pada Tabel 2. 
Tabel 2. Hasil Pengukuran Kelistrikan Sludge Battery

\begin{tabular}{ccc}
\hline $\begin{array}{c}\text { Jenis } \\
\text { lumpur }\end{array}$ & $\begin{array}{c}\text { Variasi } \\
\text { sludge } \\
\text { battery }\end{array}$ & $\begin{array}{c}\text { Densitas } \\
\text { daya listrik } \\
\left(\mathbf{m W} / \mathbf{m}^{2}\right)\end{array}$ \\
\hline Lumpur & Satu bejana & 23,580 \\
Laut & $\begin{array}{c}\text { Dua bejana } \\
\text { lumpur-air }\end{array}$ & 29,136 \\
& Satu bejana & 18,484 \\
Lumpur & Dua bejana & 21,513 \\
Danau & lumpur-air & 20,401 \\
& Satu bejana & 26,515 \\
Lumpur & Dua bejana & 30,073 \\
Sawah & lumpur-air & 26,361 \\
& Satu bejana & 42,207 \\
Lumpur & Dua bejana & 46,766 \\
Sungai & lumpur-air & 31,251 \\
\hline
\end{tabular}

Tabel 3. Hasil Perhitungan Densitas Listrik Sludge Battery

\begin{tabular}{ccccc}
\hline $\begin{array}{c}\text { Jenis } \\
\text { lumpur }\end{array}$ & $\begin{array}{c}\text { Variasi } \\
\text { sludge } \\
\text { battery }\end{array}$ & $\begin{array}{c}\text { Tegangan } \\
(\mathbf{V})\end{array}$ & $\begin{array}{c}\text { Arus } \\
(\mathbf{m A})\end{array}$ & $\begin{array}{c}\text { Beban } \\
(\mathbf{k} \boldsymbol{\Omega})\end{array}$ \\
\hline Lumpur & 1 bejana & 0,482 & 0,477 & 1 \\
Laut & 2bejana & 0,535 & 0,531 & 1 \\
& lumpur-air & 0,524 & 0,530 & 1 \\
Lumpur & 1 bejana & 0,429 & 0,421 & 1 \\
Danau & 2 bejana & 0,460 & 0,456 & 1 \\
& lumpur-air & 0,445 & 0,447 & 1 \\
Lumpur & 1 bejana & 0,515 & 0,502 & 1 \\
Sawah & 2 bejana & 0,540 & 0,543 & 1 \\
& lumpur-air & 0,502 & 0,512 & 1 \\
Lumpur & 1 bejana & 0,640 & 0,643 & 1 \\
Sungai & 2 bejana & 0,672 & 0,666 & 1 \\
& lumpur-air & 0,550 & 0,554 & 1 \\
\hline
\end{tabular}

Pada Tabel 2 dapat dilihat nilai tegangan dan arus keluaran pada lumpur danau menghasilkan keluaran terendah dibandingkan variasi lumpur lainnya.

Sedangkan pada Tabel 3 dapat dilihat hasil perhitungan Densitas daya listrik menggunakan Persamaan 8. Substrat lumpur sungai menunjukkan nilai densitas daya listrik terbesar baik itu melalui sistem satu bejana, dua bejana lumpur-lumpur ataupun dua bejana lumpur-air.

Sludge battery menggunakan sistem dua bejana lumpur-lumpur secara garis besar lebih baik dibandingkan menggunakan sistem yang lain jika ditinjau dari keluaran tegangan, arus dan densitas daya listrik yang dihasilkan, tetapi kalau ditinjau dari segi ekonomis sistem satu bejana lebih baik, karena walaupun keluaran listrik yang dihasilkan berbeda, selisih keluaran yang diperoleh dari kedua sistem tersebut tidak terlalu jauh.

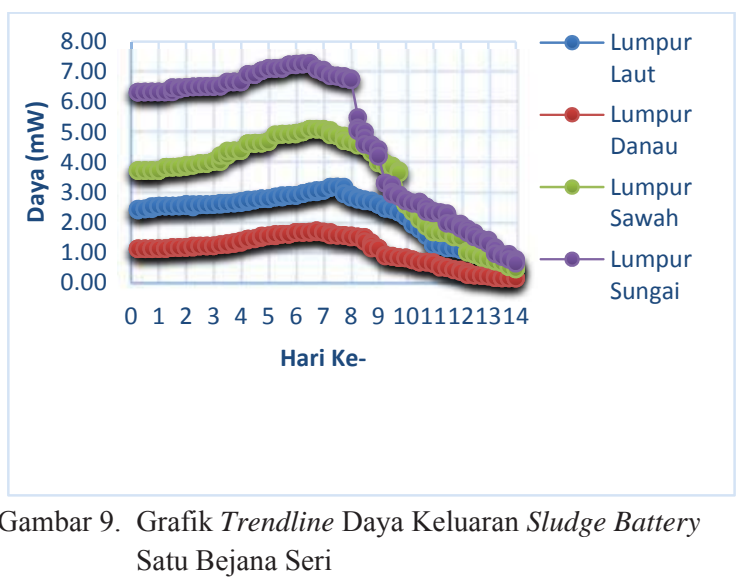

Hasil Pengujian Sludge Battery dengan Rangkaian Seri

Pada pengujian sludge battery yang disusun menjadi 8 bejana terhubung seri dilakukan pengujian lama penggunaan LED untuk mengukur tegangan dan arus. Data diambil dengan interval 2 jam sekali selama 14 hari untuk setiap jenis variasi dari lumpur yang digunakan.

Grafik trendline daya yang dihasilkan pada pengujian sludge battery bejana seri yang menggunakan elektroda tembaga sebagai anoda dan elektroda seng sebagai katoda dapat dilihat pada Gambar 4.4.

Berdasarkan Gambar 9 dapat diketahui bahwa lumpur laut dengan daya awal 2,4 $\mathrm{mW}$ terus mengalami kenaikan yang cukup signifikan hingga hari ke-8, yaitu dengan daya maksimal $3,16 \mathrm{~mW}$, setelah itu terus terjadi penurunan yang cukup curam hingga hari terakhir pengujian yaitu $0,44 \mathrm{~mW}$ dengan daya keluaran sebesar $0,13 \mathrm{~mW}$.

Kenaikan daya yang cukup signifikan dari hari ke-1 sampai hari ke-7 ini disebabkan oleh aktivitas dari bakteri pada lumpur yang bertambah setelah bakteri tersebut berkembang biak. Akibat dari jumlah bakteri yang bertambah elektron yang teroksidasi menjadi lebih banyak sehingga dampak pada produksi keluaran listrik yang dihasilkan juga semakin besar, sedangkan penurunan ekstrim terjadi karena bahan organik yang ada pada lumpur sudah mulai habis teroksidasi, sehingga elektron yang ditransfer ke elektroda menjadi berkurang. Hal ini juga berdampak pada keluaran tegangan dan arus yang dihasilkan menjadi berkurang, sehingga daya yang didapat juga menurun drastis.

\section{Hasil Pengujian Sludge Battery dengan Metode Dua Bejana Seri Lumpur-air \\ Grafik trendline daya keluaran yang dihasilkan pada pengujian sludge battery dengan sistem dua bejana seri lumpur-air dapat dilihat pada Gambar 10.}




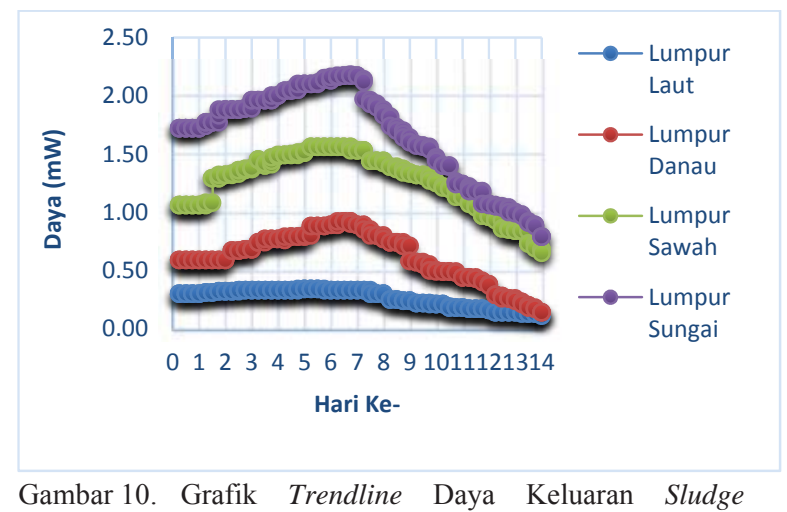

Battery Dua Bejana Seri Lumpur-air

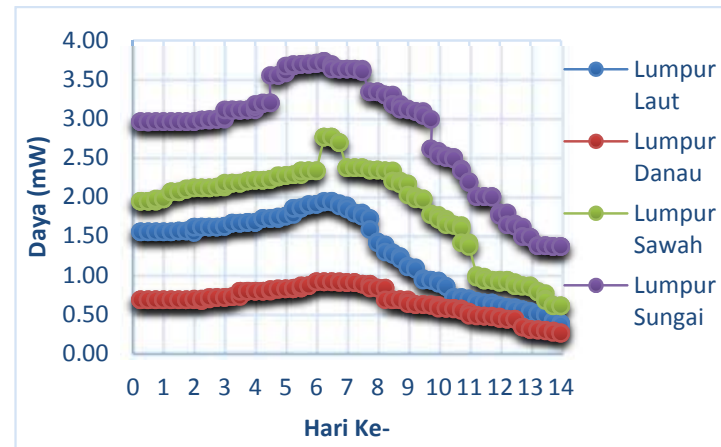

Gambar 11. Grafik Trendline Daya Keluaran Sludge Battery Dua Bejana Seri Lumpur-lumpur

Pada Gambar 10 dapat diketahui bahwa lumpur laut dengan daya awal $0,30 \mathrm{~mW}$ terus mengalami kenaikan menjadi 0,33 mW hingga hari ke-8, kemudian keluaran daya yang dihasilkan mengalami penurunan menjadi $0,25 \mathrm{~mW}$ pada hari ke-9, setelah itu terus mengalami penurunan daya seiring dengan turunnya tegangan dan arus yang dihasilkan oleh sistem dua bejana seri lumpur-air tersebut.

Pada lumpur danau daya awal yang dihasilkan adalah 0,59 $\mathrm{mW}$, jauh lebih besar dibandingkan dengan daya awal yang dihasilkan lumpur laut. Daya keluaran tertinggi yang dihasilkan oleh lumpur danau terjadi pada hari ke-7 dengan nilai $0,92 \mathrm{~mW}$, sedangkan daya terendah dihasilkan pada hari terakhir yaitu sebesar 0,14 $\mathrm{mW}$, setelah terjadi penurunan cukup drastis dari hari ke-8. Pola penaikan dan penurunan yang sama juga terjadi pada lumpur sawah dan lumpur sungai. Daya awal yang dihasilkan yaitu 1,06 $\mathrm{mW}$ dan 1,72 $\mathrm{mW}$. Setelah itu terjadi kenaikan hingga hari ke-7 dengan keluaran maksimal sebesar 2,52 $\mathrm{mW}$ dan 2,47 $\mathrm{mW}$, kemudian daya keluaran pada lumpur mengalami penurunan di hari ke-8 menjadi 2,44 $\mathrm{mW}$ dan 2,23 $\mathrm{mW}$. Penurunan berlanjut hingga hari ke-14 dengan keluaran daya sebesar $0,65 \mathrm{~mW}$ dan $0,67 \mathrm{~mW}$.

40

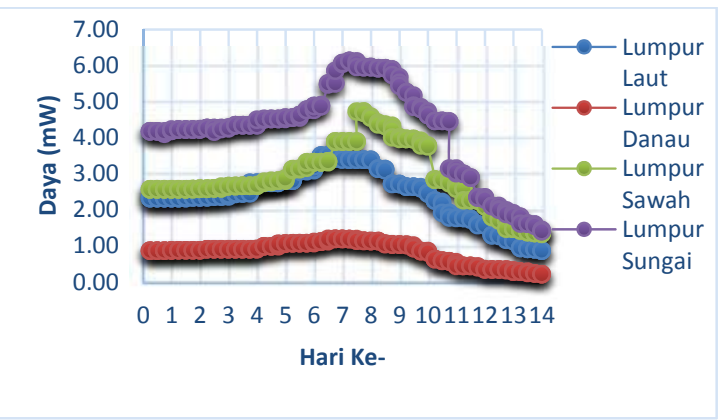

Gambar 12. Grafik Trendline Daya Keluaran Sludge Battery Stack Series

\section{Hasil Pengujian Sludge Battery dengan Metode Dua} Bejana Seri Lumpur-lumpur

Grafik trendline keluaran daya yang dihasilkan dapat dilihat pada Gambar 11 .

Berdasarkan Gambar 11 dapat diketahui bahwa lumpur laut dengan data awal $1,55 \mathrm{~mW}$ terus mengalami kenaikan hingga hari ke-7, yaitu dengan daya maksimal $1,94 \mathrm{~mW}$, setelah itu terjadi penurunan yang cukup signifikan hingga hari terakhir pengujian yaitu $0,36 \mathrm{~mW}$, sedangkan pada lumpur danau kenaikan daya yang cukup konstan hingga hari ke-7 yaitu sebesar 0,91 mW, kemudian pada hari yang sama juga terjadi penurunan daya sampai hari terakhir pengujian dengan daya keluaran sebesar 0,25 mW.

Kenaikan yang sama juga terjadi pada lumpur sawah dan lumpur sungai dengan daya awal sebesar 1,94 mW dan 2,96 mW. Selain itu daya yang dihasilkan oleh lumpur sawah dan lumpur sungai menurun hingga $0,60 \mathrm{~mW}$ dan 1,36 $\mathrm{mW}$ pada hari ke-14.

Kenaikan daya yang terjadi dari hari pertama sampai hari ke-7 disebabkan oleh aktivitas bakteri dari lumpur yang sudah bertambah karena berkembang biak, oleh karena itu jumlah elektron yang teroksidasi juga bertambah seiring dengan bertambah jumlah bakteri tersebut.

\section{Hasil Pengujian Sludge Battery dengan Metode Stack Series}

Grafik trendline daya yang dihasilkan pada pengujian sludge battery stack series dapat dilihat pada Gambar 12.

Berdasarkan Gambar 12 dapat diketahui bahwa lumpur laut dengan daya awal 2,32 $\mathrm{mW}$ terus mengalami kenaikan yang cukup signifikan hingga hari ke-7, yaitu dengan daya maksimal $3,49 \mathrm{~mW}$, setelah itu terus terjadi penurunan yang cukup curam hingga hari terakhir pengujian yaitu $0,86 \mathrm{~mW}$. Adapun pada lumpur danau daya awal yang dihasilkan adalah $0,86 \mathrm{~mW}$, kemudian terjadi kenaikan daya hingga hari ke-7 dengan daya 


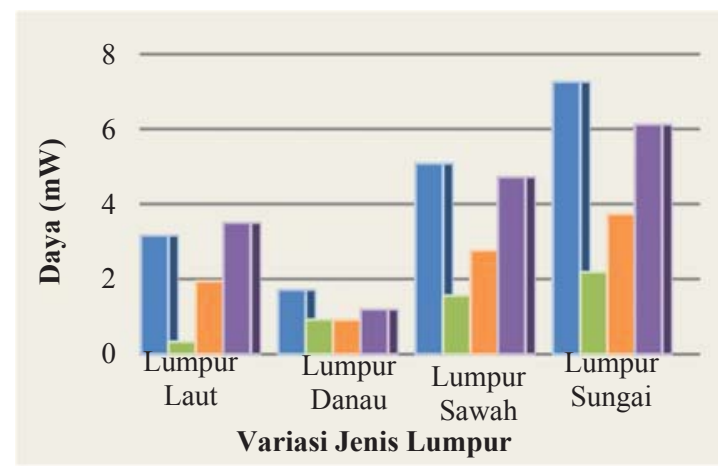

Gambar 13. Grafik Perbandingan Daya Sludge Battery pada Setiap Metode terhadap Variasi Lumpur

maksimal 1,19 $\mathrm{mW}$, setelah itu masih pada hari yang sama terjadi penurunan daya menjadi $1,18 \mathrm{~mW}$, begitu seterusnya sampai hari terakhir pengujian dengan daya keluaran sebesar $0,21 \mathrm{~mW}$.

Pola penurunan yang sama juga terjadi pada lumpur sawah dan lumpur sungai dengan daya awal sebesar 2,56 $\mathrm{mW}$ dan 4,17 $\mathrm{mW}$. Pada hari terakhir pengujian, daya keluaran lumpur sawah terus mengalami penurunan dengan keluaran 1,33 $\mathrm{mW}$, begitupun dengan lumpur sungai terus terjadi penurunan sampai hari ke-14 dengan daya keluaran 1,40 $\mathrm{mW}$.

Kenaikan daya yang cukup signifikan dari hari ke1 sampai hari ke-7 ini disebabkan oleh aktivitas dari bakteri pada lumpur yang bertambah setelah bakteri tersebut berkembang biak. Adapun akibat dari jumlah bakteri yang bertambah, elektron yang teroksidasi menjadi lebih banyak sehingga dampak pada produksi keluaran listrik yang dihasilkan juga semakin besar, sedangkan penurunan ekstrim terjadi karena bahan organik yang ada pada lumpur sudah mulai habis teroksidasi, sehingga elektron yang ditransfer ke elektroda menjadi berkurang. Hal ini juga berdampak pada keluaran tegangan dan arus yang dihasilkan menjadi berkurang, sehingga daya yang didapat juga menurun drastis, setelah itu pengaruh dari konduktivitas listrik yang dihasilkan oleh setiap lumpur juga berpengaruh pada kekuatan ionik pada lumpur tersebut sehingga kemampuan transfer elektron ataupun proton pada sludge battery berbeda-beda seiring dengan jenis variasi lumpur yang digunakan.

Setelah semua pengujian telah dilakukan, baik itu menggunakan metode satu bejana seri, metode dua bejana seri lumpur-air, metode dua bejana seri lumpurlumpur dan metode stack series, maka didapatlah perbandingan hasil keluaran dari daya yang dihasilkan oleh sludge battery. Grafik perbandingan daya yang dihasilkan dari setiap metode terhadap variasi lumpur uji ditunjukkan pada Gambar 13.
Pada Gambar 13 dapat dilihat bahwa daya maksimal yang tertinggi dihasilkan pada metode satu bejana seri untuk jenis lumpur sungai dengan besar keluaran 7,26 $\mathrm{mW}$, sedangkan untuk keluaran daya maksimal terendah dihasilkan oleh keluaran lumpur laut pada metode dua bejana lumpur-air dengan keluaran $0,33 \mathrm{~mW}$. Secara ratarata daya tertinggi yang dihasilkan oleh sludge battery terdapat pada jenis variasi lumpur sungai, sedangkan yang terendah terdapat pada jenis lumpur danau. Hal ini dipengaruhi oleh beberapa faktor, salah satunya adalah konduktivitas listrik yang dihasilkan oleh setiap jenis lumpur. Dari pengujian yang telah dilakukan didapat konduktivitas listrik tertinggi ada pada lumpur sungai. Hal ini berdampak dengan keluaran listrik yang dihasilkan, karena besar konduktivitas listrik dari suatu substrat mengindikasikan kekuatan ionik yang dimiliki oleh substrat tersebut. Semakin besar kekuatan ionik dari jenis substrat maka semakin cepat pula proses oksidasi dan reduksi yang terjadi pada MFC, sehingga elektron yang ditransfer dari anoda dan katoda menjadi lebih banyak yang menyebabkan tegangan ataupun arus keluaran semakin besar.

\section{PENUTUP}

\section{Kesimpulan}

1. Konduktivitas listrik tertinggi dihasilkan oleh lumpur sungai mencapai $3,63 \mathrm{mS} / \mathrm{cm}$, sedangkan yang terendah adalah lumpur danau dengan nilai konduktivitas $0,35 \mathrm{mS} / \mathrm{cm}$.

2. Densitas daya listrik tertinggi dihasilkan oleh lumpur sungai dengan metode dua bejana lumpur-lumpur yaitu sebesar $46,766 \mathrm{~mW} / \mathrm{m}^{2}$, sedangkan densitas daya listrik yang terendah pada lumpur danau yaitu sebesar $18,040 \mathrm{~mW} / \mathrm{m}^{2}$.

3. Daya listrik tertinggi dihasilkan oleh lumpur sungai melalui sistem satu bejana seri dengan daya maksimal sebesar 7,26 $\mathrm{mW}$, sedangkan untuk daya yang terendah terdapat pada lumpur laut dengan sistem dua bejana lumpur-air yaitu sebesar $0,30 \mathrm{~mW}$.

4. Pola kenaikan tegangan ataupun arus yang dihasilkan sludge battery rata-rata sampai hari ke-7, kemudian terjadi penurunan hingga hari terakhir pengujian.

5. Potensi energi listrik terbesar didapat oleh lumpur sungai menggunakan sistem satu bejana seri dengan tegangan maksimal mencapai $5,38 \mathrm{~V}$ dan bertahan hingga 14 hari pemakaian.

\subsection{Saran}

Kinerja sludge battery yang dibuat belum maksimal karena tegangan dan arus yang dihasilkan belum konstan terhadap waktu pemakaian sludge battery sehingga masih harus dicari alternatif untuk menjaga keluaran tetap konstan, selain itu perlu dilakukan pengembangan tentang 
microbial fuel cell dalam skala lebih besar dalam bentuk pembangkit listrik tenaga lumpur sehingga arus dan tegangan maksimal dapat tercapai pada penelitian berikutnya.

\section{REFERENSI}

[1] Setiawan R, Hari Harbeno, Wisnu S 2014. Sea Water Battery. Bengkulu. Universitas Bengkulu.

[2] Muhlisin, M, Noer S. 2015. Pemanfaatan Sampah Kulit Pisang dan Kulit Durian Sebagai Bahan Alternatif Pengganti Pasta Batu Baterai. Jurnal Rekayasa dan Teknologi Elektro. Universitas Lampung.

[3] Logan BE. 2008. Microbial Fuel Cell. New Jersey: John Wiley \& Sons. 216 p.

[4] Rabaey K, Verstraete W. 2005. Microbial Fuel Cells: Novel Biotechnology For Energy
Generation. Trends in Biotechnology 23(6):291298.

[5] Logan BE, Hamelers B, Rozendal R, Schroder U, Keller J, Freguia S, Aelterman P, Verstraete W, Rabaey K. 2006. Microbial Fuel Cells: Methodology And Technology. Environmental Science and Technology 40:5181-5192.

[6] Du Z, Li H, Gu T. 2007. A State Art Review On Microbial Fuel Cells: A Promising Technology For Wastewater Treatment And Bioenergy. Biotech. Adv. 25: 464482.

[7] Degrenne Nicolas. 2012. Power Management for Microbial Fuel Cells. Electric Power. Ecole Centrale de Lyon. English.

[8] Rinaldi, Wahyu. 2014. Pengolahan Limbah Cair Organik dengan Microbial Fuel Cell. Jurnal Rekayasa Kimia dan Lingkungan Vol. 10, No. 2, Hlm. 92 - 98, ISSN 1412-5064. 